\title{
ПРОБЛЕМНО-ЦІЛЬОВІ ЗАСАДИ СТРАТЕГІЧНОГО ПЛАНУВАННЯ РОЗВИТКУ СИСТЕМИ ОСВІТИ РЕГІОНУ
}

Сиченко В.В., ректор, д-р наук $з$ держ. упр., професор, КЗВО «Дніпровська академії неперервної освіти», Дніпро, Україна

Хитько М.M., канд. наук 3 держ. упр., доцент КЗВО «Дніпровська академії неперервної освіти», Дніпро, Україна

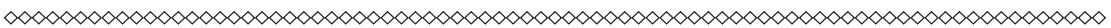

У статті досліджується необхідність та особливості стратегічного планування освітнього розвитку на регіональному рівні з використанням наявних проблем у якості основи цілепокладання управлінської діяльності. На основі системного аналізу та виокремлення спільного $і$ особливого у тенденціях освітнього розвитку на рівні країни та регіону визначаються базові проблеми стратегічного планування та управління. Здійснюється узагальнюючий аналіз розвитку регіональної системи освіти на прикладі Дніпропетровської області з виходом на постановку стратегічних иілей ї̈ реформування.

Показано щзо основою стратегічного планування розвитку освіти є розроблення нового цілепокладання розвитку української освіти на базі цінностей демократичного суспільства, особистісного розвитку, спрямованості до європейського освітнього простору; створення каркаса нового законодавчого поля функціонування освіти;визначення засад рівного доступу кожного громадянина до якісної освіти всіх рівнів як магістральний напрям ї̈ розвитку; формування змісту освіти на основі державних стандартів як важеля управління якістю освіти в країні.

Акиентуються проблеми стратегізації управління освітою на регіональному рівні та необхідність пов'язаних з циим інновацій y нормативно-організаційній царині. Показано щзо в основі 596 
Проблемно-иільові засади стратегічного планування розвитку системи освіти регіону освітньої парадигми має лежати завдання забезпечення потреб споживачів освітніх послуг, розиирення можливостей доступу до якісної освіти, забезпечення ефективного соиіального механізму конкурентоздатності випускників икіл на сучасному ринку праці. На основі проведеного дослідження робляться пропозиції щуодо удосконалення стратегічного планування розвитку основних складових регіональної системи освіти.

Ключові слова: стратегічне планування, регіональне управління, регіональна система освіти, оптимізачія держсавного управління, изіле покладання управління.

Постановка проблеми у загальному вигляді. Приймаючи виклики сьогодення, українське суспільство прагне модернізуватися на інноваційній основі, аби набути прискорення, характерного для глобального світового поступу. Головним рушієм цього процесу завжди були і незмінно залишаться люди — компетентні i кваліфіковані, конструктивні і конкурентоспроможні, компромісні i консенсусні. У розвитку людського потенціалу, людського капіталу ключову i, головне, безперервно зростаючу роль відіграє освіта. Виключно завдяки освітній складовій в індексах людського розвитку та глобальної конкурентоспроможності Україна за цими показниками утримує серединні позиції в колі багатьох країн світу. Водночас дедалі стає очевидним, що екстенсивний шлях зростання вітчизняної освіти себе повністю вичерпав. На порядку денному досягнення нею нових якісних характеристик, які відповідають вимогам сьогодення. Їх досягнення вимагає чіткого стратегічного планування освітнього розвитку як на національному, так i регіональному рівнях.

Аналіз останніх досліджень і публікацій. Сучасний період стратегії модернізації вітчизняної освіти розпочато у 2014 р., у якому новий погляд на якісний рівень та суспільну роль освіти зумовили Революція гідності, а також підписання Угоди про асоціацію України 3 Європейським Союзом. У державній стратегії пріоритетними $є$ 
«Public Administration and Regional Development»

https://pard.mk.ua/index.php/journal

орієнтири щодо людиноцентризму, забезпечення якості і доступності, конкурентоспроможності й ефективності, інтеграції в європейські та світові простори освіти і досліджень, періодичного національного і міжнародного моніторингу, комплексного аналізу стану і перспектив розвитку освіти, стабільного необхідного і достатнього забезпечення фінансовими та інтелектуальним ресурсами. Державна освітня стратегія покликана змінювати ставлення суспільства до освіти $з$ огляду на перспективу реформування освітньої сфери, як того вимагають євроінтеграційні та глобалізаційні виклики XXI ст. Її окремі складові досліджуються у роботах Я. Мельник, В. Кременя, С. Одайник, А. Ревко, С. Тульчинської та інших авторів. Разом 3 тим на периферії досліджень залишається регіональний аспект стратегічного планування освітнього розвитку на проблемноцільовій основі.

Формулювання цілей статті (постановка завдання). Визначення базових проблем регіональної освіти як основи стратегічного планування іiі розвитку.

Виклад основного матеріалу дослідження. Саме для XXI ст. стає характерним розуміння того, що освіта не може надалі залишатися у сфері відокремленої галузевої чи відомчої політики, розглядатися як витратне соціальне благо та безповоротна стаття видатків, а є продуктивним чинником й умовою розвитку, відтак повинна набути статусу загальнонаціональної стратегії. Загальноцивілізаційні тенденції викликали появу нової парадигми освіти, їі переорієнтацію з держави на людину, на фундаментальні людські цінності, на послідовну демократизацію освітнього процесу й освітньо-педагогічної ідеології загалом [2, с.10].

Сучасна освітня стратегія має реалізовуватись у контексті потреб модернізації країни, згідно зі Стратегією сталого розвитку «Україна - 2020» (2015 р.), Угодою про асоціацію між Україною та Європейським Союзом(2014 p.), іншими стратегічними документами української держави, що визначають ії європейський і світовий статус у майбутньому. 3 урахуванням кризового економічного стану країни потрібно насамперед визначити найважливіші освітні проблеми та обгрунтувати способи їх розв'язання в найближчі 
Проблемно-иільові засади стратегічного планування розвитку системи освіти регіону роки та в перспективі. Очевидно, що реформування не може бути успішним, якщо здійснюється як потік постійних, локальних змін, часто суперечливих, концептуально не об'єднаних, не має широкої підтримки та розуміння в освітян і суспільстві.

Назагальнодержавному рівні основою стратегічного планування розвитку освіти є розроблення нового цілепокладання розвитку української освіти на базі цінностей демократичного суспільства, особистісного розвитку, спрямованості до європейського освітнього простору; створення каркаса нового законодавчого поля функціонування освіти; визначення засад рівного доступу кожного громадянина до якісної освіти всіх рівнів як магістральний напрям їі розвитку; формування змісту освіти на основі державних стандартів як важеля управління якістю освіти в країні; створення ресурсів для переходу на 12-річну загальну середню освіту; перехід до варіативної освіти; запровадження незалежного зовнішнього оцінювання; упровадження нової моделі атестації і державної акредитації; поширення інформаційних та загалом інноваційних освітніх технологій; рух до багатоканального фінансування галузі; становлення державно-громадського управління [4, с.26].

Разом 3 тим слід вказати і на наявні системні проблеми, які мають стати основою визначення стратегічних напрямів розвитку галузі. Це відсутність системної науково обгрунтованої ідеології розвитку освіти $з$ послабленням їі культуротворчої місії; згортання низки освітніх мереж, зокрема, дошкільної, в умовах відсутності прогнозу демографічної ситуації і потреб розвитку освіти на регіональному рівні; невизначеність функцій професійно-технічних навчальних закладів i технікумів, училищ, коледжів у нових ринкових умовах, інноваційній економіці; неадекватне розширення мережі вищої освіти 3 ризиками здобуття молоддю неякісної освіти; невирішеність проблем корупції і хабарництва; відсутність ефективного моніторингу реформ тощо. Загалом українська освіта фактично не стала загальнонаціональним пріоритетом [11, с.135].

Регіональна система освіти розвивається у межах загальнонаціональних тенденцій, досягнень та проблем. Узагальнення статистичних даних дає уявлення про базові тренди 
«Public Administration and Regional Development»

https://pard.mk.ua/index.php/journal

та підстави стратегічного планування основних складових регіональної системи освіти.

Значущість дошкільної освіти постійно зростаєпо мірі усталення високого статусу дитинства, наростання кількості міжнародних документів про охорону дитинства, і особливо після проведення у 2010 р. під егідою ЮНЕСКО Всесвітньої конференцію з навчання, виховання і розвитку дітей раннього і дошкільного віку, базові положення якої відображені у законах України «Про дошкільну освіту» та «Про охорону дитинства», у Національній стратегії розвитку освіти України до 2021 р. Однак слід констатувати, що економічні та управлінські негаразди призвели до скорочення кількості дитячих садків, мережа дошкільних навчальних закладів не була збережена див. рис. 1.

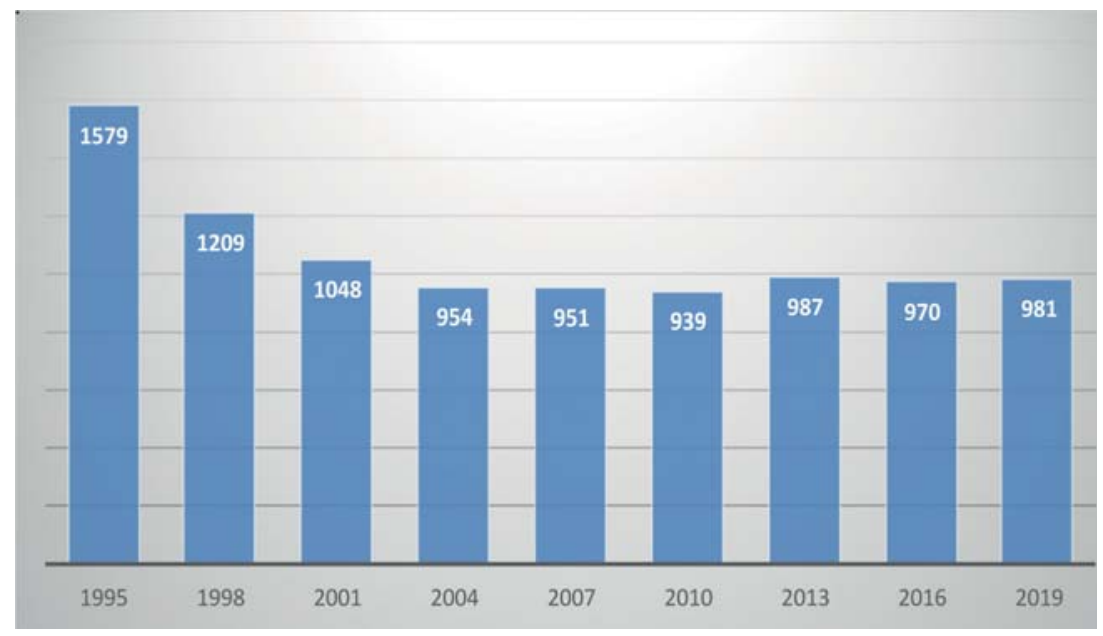

Pис.1. Кількість закладів дошкільної освіти, од. Джерело:[1]

У 2010 р. дошкільну освіту п'ятирічних дітей було визнано обов'язковою. Наслідком цих змін стало те, що майже всі діти старшого дошкільного віку охоплені різними формами здобуття дошкільної освіти, однак молодші категорії дошкільнят значною мірою залишаються за межами організованих форм соціалізації. 600 Isue DOI: $10.34132 /$ pard 
Проблемно-иільові засади стратегічного планування розвитку системи освіти регіону Сьогодні у регіоні досить великою є проблема нестачі місць у дошкільних закладах, збільшується наповненість у групі, що виступає небезпечним фактором зниження якості освіти див. рис. 2 та рис. 3.

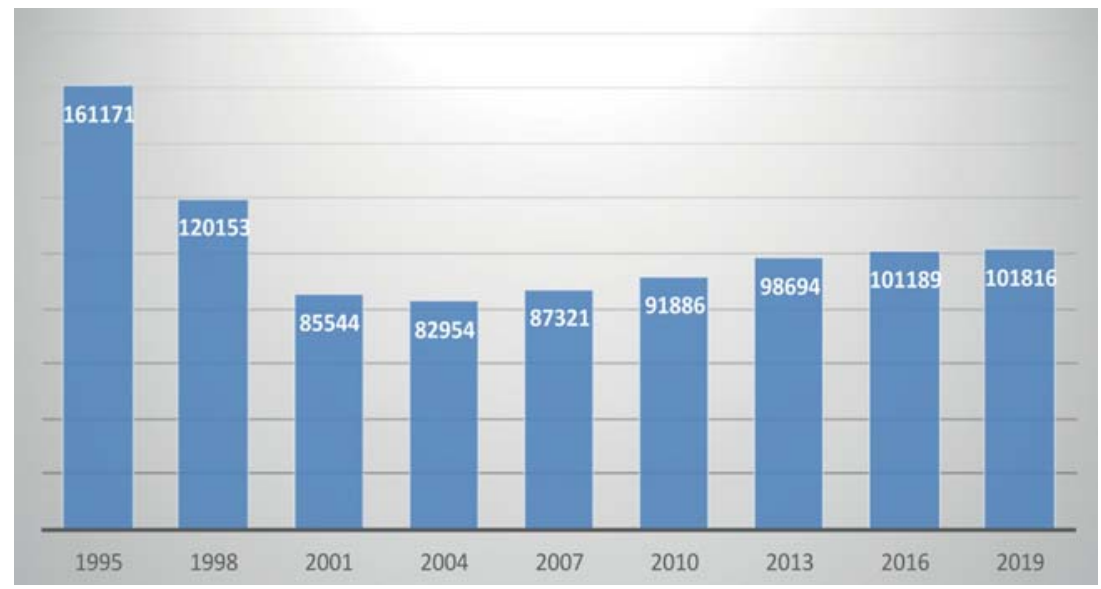

Рис.2. Кількість місиь в закладах дошкільної освіти. Джерело:[1]

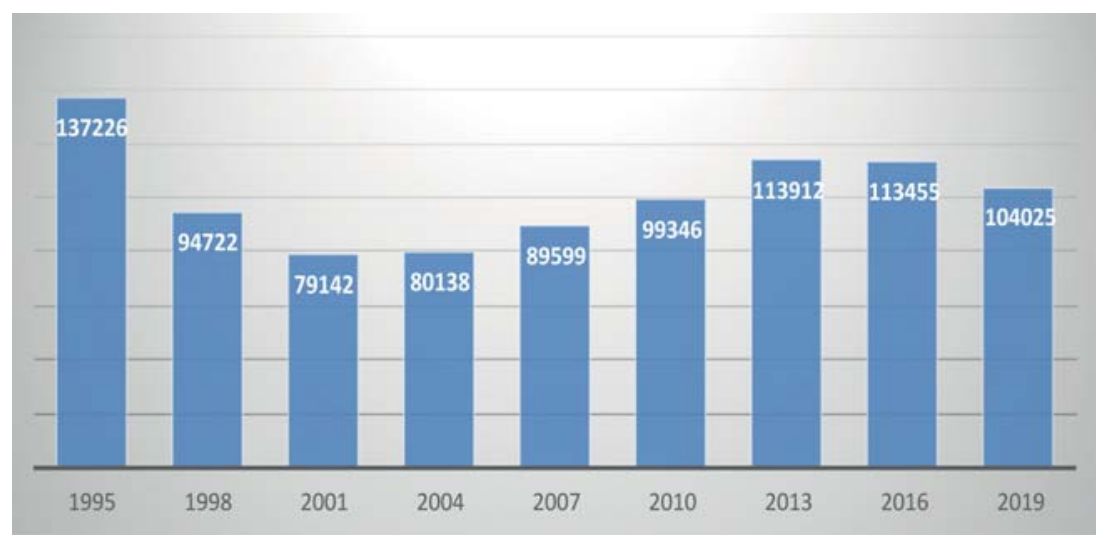

Рис.3. Кількість осіб в закладах дошкільної освіти. Дюерело:[1] 


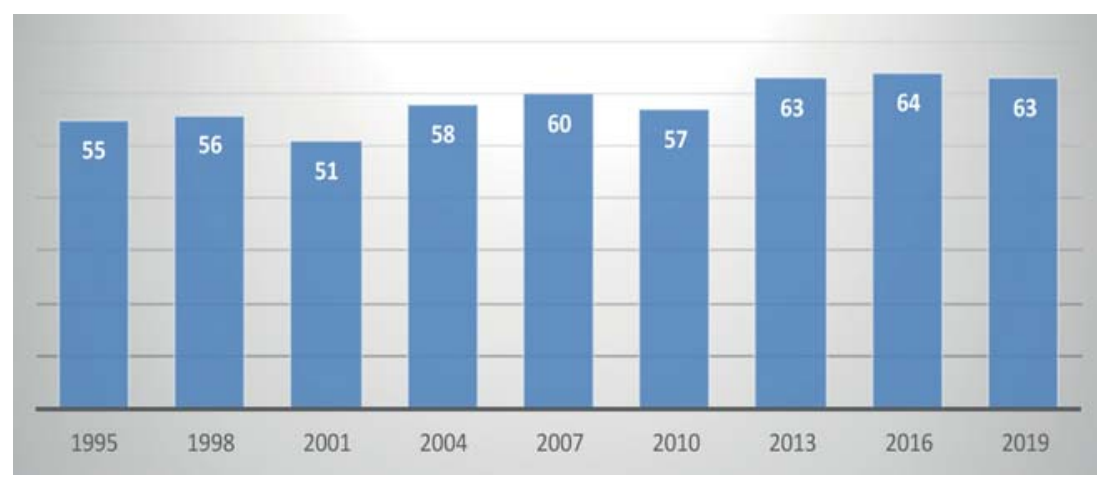

Рис.4. Охоплення дітей в закладах дошкільної освіти, \%. Джерело:[1]

Ключовим перспективним розв'язанням проблеми доступності дошкільної освіти може бути впровадження кращого зарубіжного досвіду функціонування мережі дошкільних навчальних закладів різних типів і форм власності: стаціонарні та сезонні ясла, садки 3 різною тривалістю, дошкільні відділення при початкових класах, материнські школи, майданчики або відкриті дитячі садки [9, с.65]. Від органів управління на місцях потрібні сприяння приватним ініціативам; створення груп з короткотривалим перебуванням у них дітей; відновлення діяльності дошкільних навчальних закладів, що тривалий час використовувались не за призначенням; відкриття на базі загальноосвітніх навчальних закладів навчально-виховних комплексів, все це сприяло б зростанню рівня охопленості дітей в системі дошкільної освіти, див. рис.4. Практична спрямованість підготовки кадрів системи дошкільної освіти потребує значного поглиблення, адресного замовлення, сучасної політики розвитку людського ресурсу.

У цілому здійснення стратегічного планування у регіональній системі дошкільної освіти вимагають такі напрями як підпорядкування реформ оптимізації життєдіяльності дитини дошкільного віку, узгодження організаційних аспектів наступності дошкільної та початкової освіти, інтеграція діяльності управлінських інституцій, що опікуються дошкільним 602 
Проблемно-цільові засади стратегічного планування розвитку системи освіти регіону дитинством, громадська учать у реформуванні дошкільної освіти, упровадження цілісної регіональної програмно-методичної моделі життєзабезпечення, підтримки та супроводу дитячого розвитку, кардинальні зміни системи духовного та фізичного виховання дітей на основі сучасних концепцій та технологій. На регіональному рівні, на нашу думку, необхідно створити єдиний центр комплексного сервісу дошкільної освіти, що забезпечить перехід від вертикального адміністрування діяльності дошкільних закладів на стратегію адаптивного сервісу на принципах поліархічногоризонтальної взаємодії усіх причетних до дошкільної галузі інституцій регіональної системи освіти.

Загальноосвітня школа забезпечує становлення учня як особистості, закладає фундамент для успішної самореалізації людини впродовж життя. I на національному, і на регіональному рівні зазнали істотної трансформації цільова спрямованість загальної середньої освіти, їізміст, організація навчального процесу, дидактико-методичне забезпечення, підходи до оцінювання освітніх результатів у напрямі посилення особистісної орієнтації освіти, ii розвивального, компетентнісного, демократичного характеру. Створено умови для розвитку обдарованості дітей, більш повного задоволення освітніх запитів і потреб учнів гімназії, ліцеї, колегіуми. Разом з тим відбувається оптимізація шкільної мережі, яка не завжди $\epsilon$ ефективною внаслідок організаційних та фінансових причин. Протягом 2010-2019 років спостерігається динаміка зменшення кількості $3 \mathrm{CO}$ див. рис. 5., на ряду із зростанням кількості учнів у ЗСО протягом 2016-2020 років, та незначним зростанням кількості учителів (див. рис. 7), у ЗСО протягом 2019-2020 років.

Серед нерозв'язаних проблем — недостатня орієнтованість шкільної освіти на практичні потреби учня у контексті особливостей регіонального розвитку; далеке від оптимального оснащення шкіл, інформаційне забезпечення регіонального простору; відсутність єдиної регіональної системи моніторингу якості загальної середньої освіти як основи управління. 
«Public Administration and Regional Development»

https://pard.mk.ua/index.php/journal

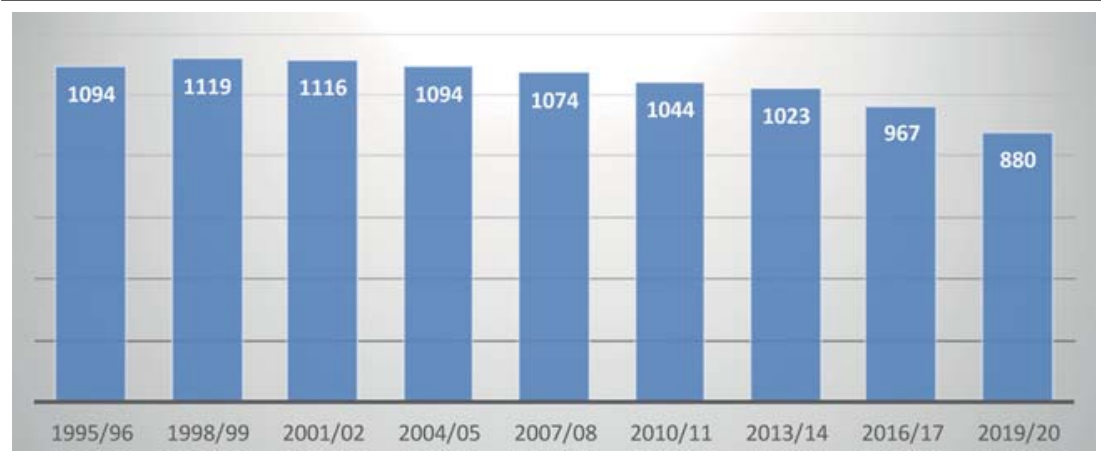

Pис.5. Кількість закладів загальної середньої освіти, од. Джерело:[1]

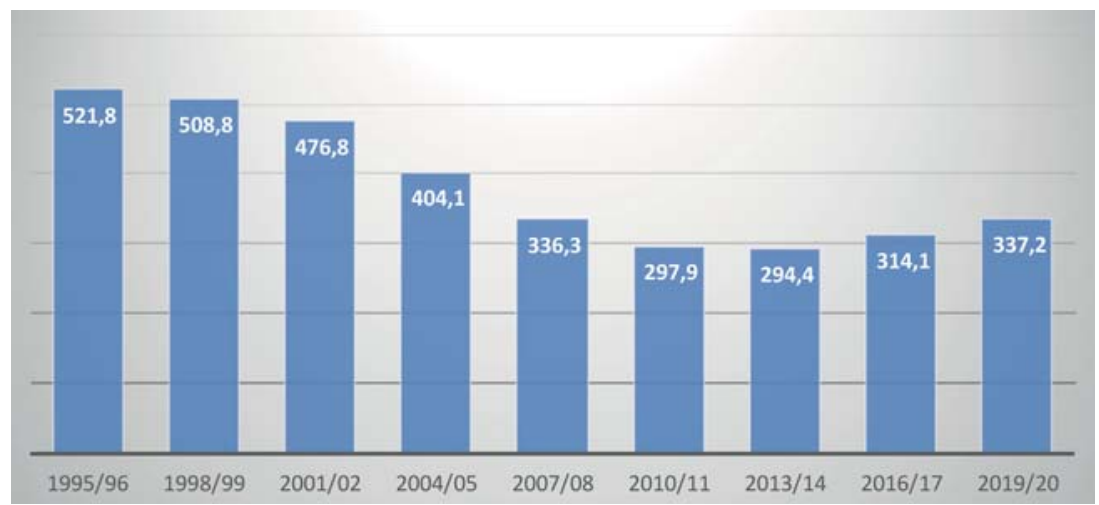

Рис.6. Кількість учнів в закладах загальної середньої освіти, тис. осіб.Джерело:[1]

Профілізація старшої школи як одна із визначальних засад ii ефективного функціонування в сучасних умовах відбувається недостатньо інтенсивно та зі значними труднощами, можна говорити про несформованість мережі шкіл, що реально забезпечують профільну спеціалізацію. Рівень комп'ютеризації школи у 5-6 разів нижчий, ніж у Європі. Зберігається нерівність у забезпеченні доступу до якісної освіти учнів сільської місцевості порівняно з міськими школярами. 


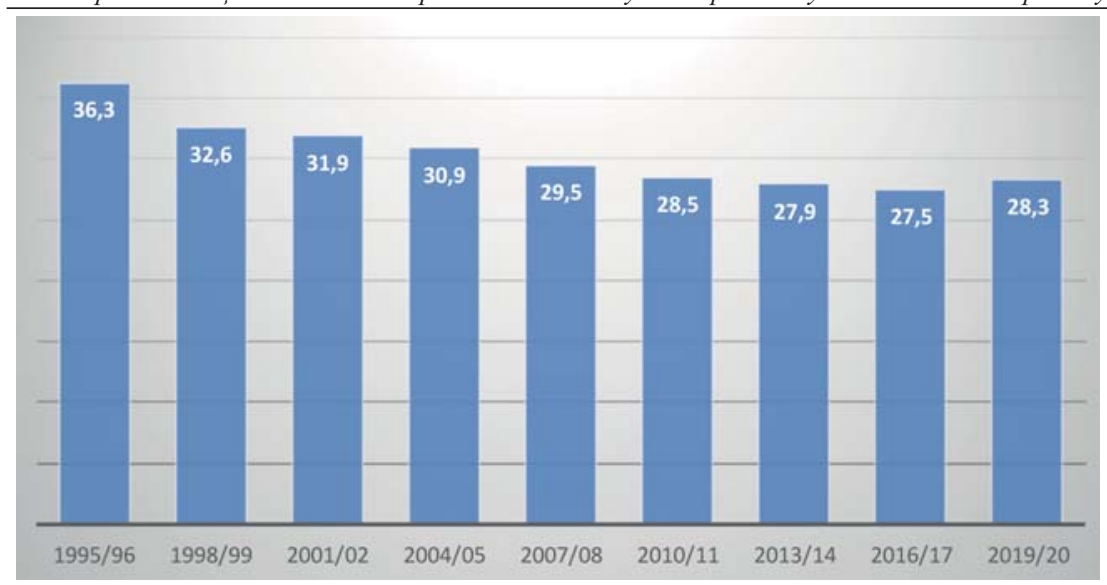

Pис.7. Кількість учителів в закладах загальної середньої освіти, тис. осіб.Джерело:[1]

Одним із напрямів реформування регіональної школи слід вважати вирішення проблеми малокомплектних навчальних закладів на основі створення освітніх округів, а також розширення можливостей для широкого використання форм індивідуального та дистанційного навчання. А головне - необхідно на рівні регіону забезпечити інтегрованість та узгодженість вирішення проблеми фінансового, управлінського, організаційного і кадрового забезпечення загальноосвітньої школи.

Регіональне стратегічне планування розвитку загальноосвітньої школи має відображати зміни у національній стратегії освітнього розвитку, нові базові цінності, які утверджують соціально та особистісно значущий сенс здобуття освіти, пріоритетність соціальної та інформаційної функцій школи [5, с.9]. У центрі регіонального стратегічного управління освітою мають бути завдання зміни структури школи, місії та цільові освітні спрямування іiі ступенів, упровадження 12-річного терміну навчання, розширення можливостей профільного навчання. Для нашого регіону 3 його промисловим потенціалом особливо важливим є становлення інноваційної моделі шкільної освіти, 
«Public Administration and Regional Development»

https://pard.mk.ua/index.php/journal

формування і розвиток інтегрованого інформаційно-освітнього середовища з використанням дистанційних технологій.

Окремої уваги потребує вирішення проблеми оптимізації мережі загальноосвітніх навчальних закладів 3 метою ефективної реалізації завдань загальної середньої освіти. В ii основі має лежати завдання забезпечення потреб споживачів освітніх послуг, розширення можливостей доступу до якісної освіти, забезпечення ефективного соціального механізму конкурентоздатності випускників шкіл на сучасному ринку праці. Разом з тим нагальною $€$ проблема збереження шкіл, особливо в сільській місцевості, як культурних й освітніх осередків. До питання закриття шкіл місцеві органи державної виконавчої влади повинні підходити виважено, враховувати демографічний прогноз, соціально-економічні умови, думку громади [6, с.84].

Важливо забезпечити функціонування у кожному сільському населеному пункті, де є діти шкільного віку, принаймні початкової школи. Вирішення цього питання потребує створення окремої регіональної цільової соціально-освітньої програми на засадах соціального партнерства 3 широким використанням виховного й освітнього потенціалу сільського соціуму. Доцільно створити й поширити мережу освітніх округів, здатних забезпечити розгалужену інфраструктуру освітнього простору регіону, кращий доступ навчальних закладів до освітніх ресурсів, підвищити якість освітніх послуг і поліпшити умови для реалізації програм профільного навчання у сільських загальноосвітніх навчальних закладах.

У професійній освіті регіону, як і країни загалом, відбулися значні трансформації, зокрема перехід до ступеневої системи навчання, запровадження нових форм підготовки 3 інтегрованих (укрупнених) професій, здійснення незалежної кваліфікаційної атестації, розширення співпраці 3 роботодавцями тощо. Поряд iз цим спостерігалися негативні тенденції: скорочення мережі та контингенту учнів ПТНЗ (див. рис. $8,9,10$ ), повільне оновлення переліку напрямів професійної підготовки, зменшення обсягів державного замовлення та фінансування професійної освіти. 
Проблемно-цілььові засади стратегічного планування розвитку системи освіти регіону

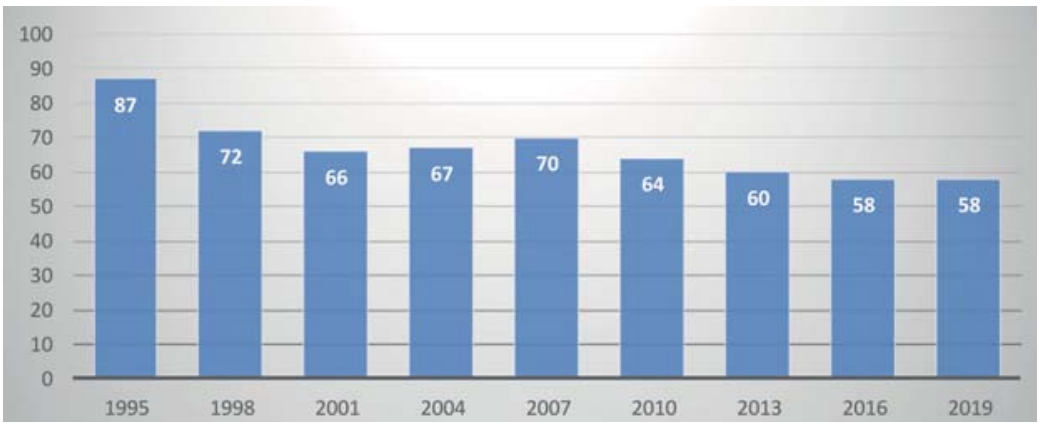

Рис.8. Кількість закладів професійної освіти, од. Джерело:[1

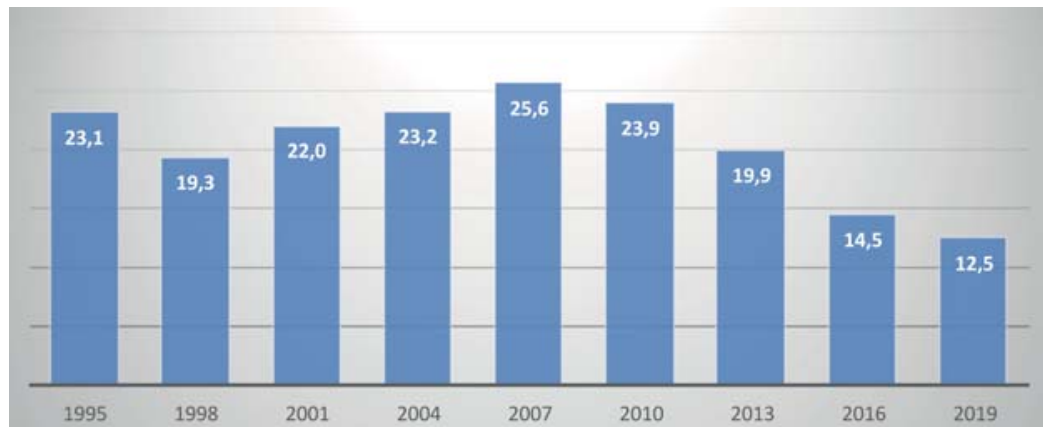

Рис.9. Кількість учнів в закладах професійної освіти, тис. осіб. Джерело:[1]

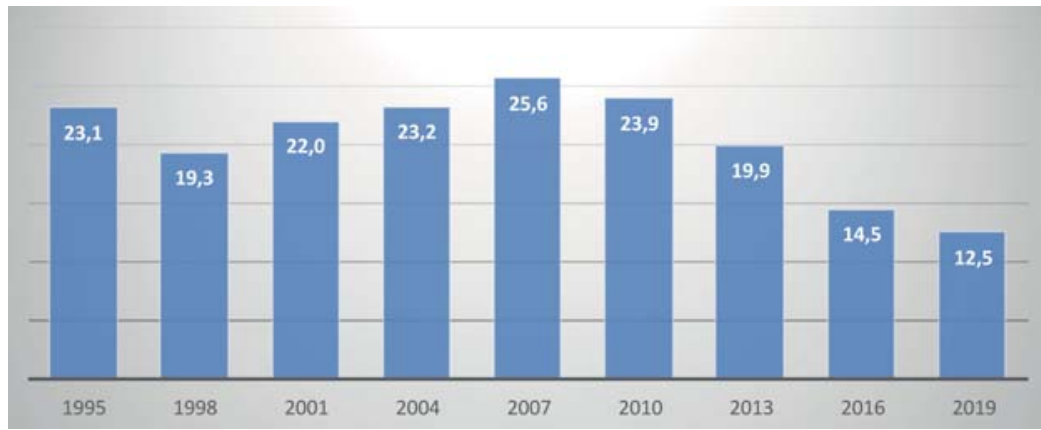

Рис.10. Кількість викладачів в закладах професійної освіти, тис. осіб.Джерело:[1] 
«Public Administration and Regional Development»

https://pard.mk.ua/index.php/journal

Сьогодні якість професійної підготовки кваліфікованих робітників і молодших спеціалістів в регіоні не повною мірою відповідає вимогам сучасного ринку праці. Основні проблеми спричинені збереженням значної централізації в управлінні професійною освітою, недостатньою взаємодією професійних навчальних закладів, роботодавців і науковців у розробленні державних стандартів професійної освіти, багатотипністю мережі ПТНЗ, недосконалістю механізмів фінансування. Неефективною $\epsilon$ система професійної орієнтації молоді на робітничі професії та консультування з професійної кар'єри в ринкових умовах. Чимало складних проблем накопичилося в організації професійного навчання на виробництві.

Стратегічним напрямом розвитку слід вважати створення багатогалузевих професійних навчальних закладів із сучасною матеріально-технічною базою 3 орієнтацією на інтегрування професій та прив' язкою підготовки фахівців до потреб національного та регіональних ринків праці. Необхідним є вирішення проблеми фінансування навчальних закладів державної форми власності на регіональному рівні на засадах, які унеможливлюють його неадекватне скорочення. Потребує також урегулювання нормативна база використання майна ПТНЗ, їх перепрофілювання, відчуження приміщень, земельних ділянок, а також скорочення робочих місць для педагогічних працівників.

Серед цілей стратегічного планування у даній сфері слід визначити прогнозування потреб регіонального ринку праці, створення дієвих механізмів соціального партнерства, використання економічних інструментів стимулювання розвитку та роботодавців до інвестування у професійну підготовку фахівців $[13$, с.126]. На нашу думку, необхідне створення маркетингових i профорієнтаційних служб у навчальних закладах. Необхідно створити ефективну систему регіонального замовлення робітничих кадрів на основі ефективної статистики та прогнозів. Потрібно також подальше розширення експериментальної апробації ефективних форм підготовки робітничих кадрів, таких як модель освітньопрофесійного кластеру 3 формування трудового потенціалу в регіоні чи модель управління маркетингом системи ПТО. Достатньо 
Проблемно-цільові засади стратегічного планування розвитку системи освіти регіону перспективним $є$ створення регіональних центрів маркетингових досліджень у сфері професійної освіти.

Особливе значення має забезпечення поетапної оптимізації мережі професійно-технічних навчальних закладів та ефективне управління ними як комунальною власністю з урахуванням науково обгрунтованих критеріїв, особливостей соціально-економічного розвитку регіону i вимог ринку праці. Доцільним $є$ створення єдиної регіональної системи професійної освіти, що поєднує різні типи професійних навчальних закладів з трансформацією існуючих у багаторівневі і багатопрофільні професійні ліцеї та коледжі. Достатньо ефективним напрямом розвитку є формування регіональних інтегрованих освітньо-професійних систем у вигляді освітньопрофесійних округів чи навчально-науково-виробничих кластерів, що поєднують заклади професійної освіти 3 регіональними підприємствами та організаціями, науковими установами.

Найбільш очевидною ознакою розвитку системи вищої освіти регіону є іiі екстенсивне зростання, в основному за рахунок радикальної зміни співвідношення університетів, академій та інститутів $з$ одного боку - та коледжів - 3 іншого. Демографічна та економічна кризи негативно позначалася на кількості закладів вищої освіти (рис. 11), та на якості надання освітніх послуг, конкурентоспроможності вищої освіти на вітчизняному та європейському ринках праці.

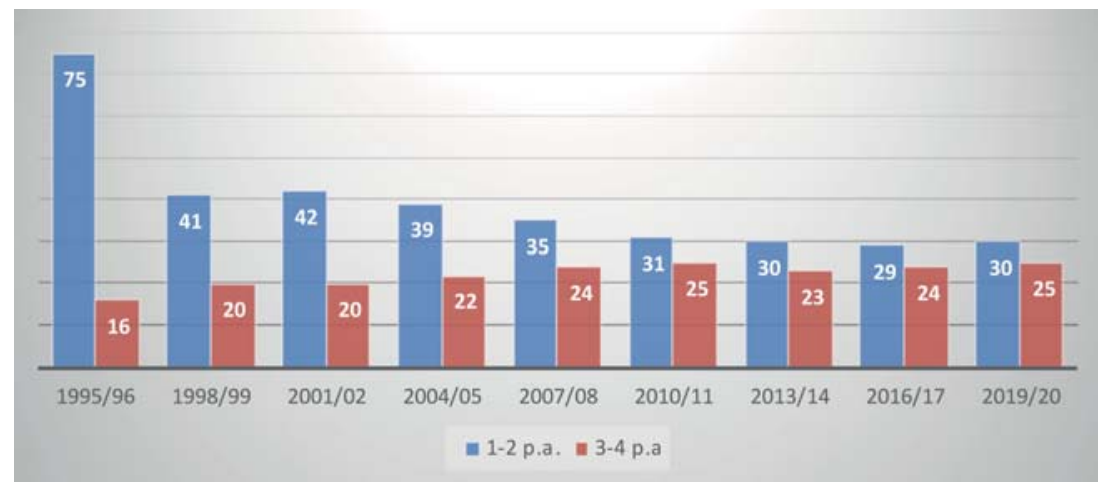

Pис.11. Кількість закладів вищої освіти, од. Джерело:[1] 


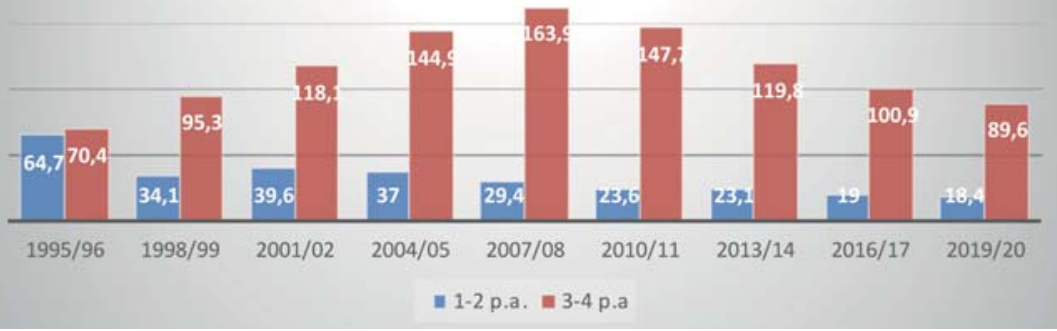

Рис.12. Кількість студентів в закладах вищої освіти, тис. осіб. Джерело:[1]

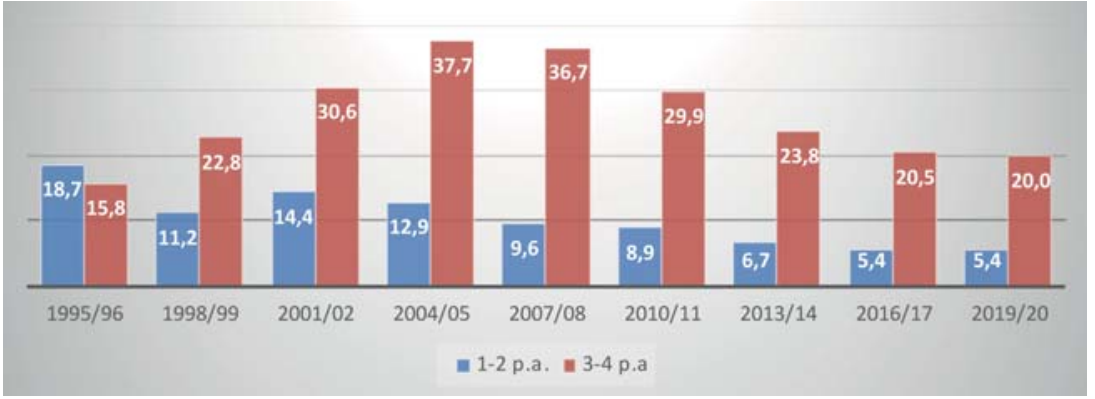

Pис.13. Кількість прийнятих на навчання в заклади вищзої освіти, тис. осіб. Джерело:[1]

Слід сказати, що мережа закладів вищої освіти державної/ комунальної форми власності регулювалося здебільшого заходами адміністративного характеру. Такі дії призводили до протестних настроїв чи відкритих протестів керівництва й студентів закладів, як, наприклад, у випадку з Дніпропетровським аграрним університетом. Адже процеси реорганізації майже завжди передбачали не скорочення державного фінансування та інших видатків, утрату усталених традицій. Між тим серед першочергових завдань $\epsilon$ створення потужних національних регіональних університетів шляхом об'єднання існуючих закладів, проте на компромісній та обгрунтованій основі. 
Проблемно-цільові засади стратегічного планування розвитку системи освіти регіону

На сьогодні можна констатувати такі риси регіональної системи вищої освіти як розпорошеність мережі закладів, низька конкурентоспроможність більшості 3 них, повільний розвиток автономії, відсутність сучасних систем внутрішнього забезпечення якості, слабкість дослідницько-інноваційної основи підготовки фахівців, низький рівень інтернаціоналізації, неефективність фінансових механізмів ресурсного забезпечення.

Однією 3 найбільших проблем є відірваність вищої освіти від потреб та інтересів ринку праці. Попит ринку праці на кваліфікованих робітників перевищує попит на фахівців із вищою освітою. Відповідно серед безробітних кількість перших на чверть менша, ніж других. Система освіти цього не відображає, і за останні чверть століття випуск кваліфікованих робітників скоротився вполовину, а випуск фахівців із вищою освітою зріс більш ніж у півтора рази [3, с.12].

Формально від місцевої влади залежить формування державного замовлення на підготовку фахівців 3 вищою освітою, оскільки саме регіональні державні адміністрації мають повноваження погоджувати пропозиції місцевих закладів вищої освіти про обсяги державного замовлення. Однак місцева влада, не маючи відповідальності за фінансування державного замовлення, як правило, підтримує будь-які пропозиції місцевих закладів про високі обсяги держзамовлення без оцінки реальної ситуації. Очевидно, до цього процесу мають залучатися органи місцевого самоврядування з відповідним перерозподілом функцій управління та фінансування. Це питання має вирішуватися у комплексі із завданням забезпечення реальної фінансової автономії державних закладів вищої освіти, які залишаються у статусі бюджетних установ.

Очевидно, що стратегічне планування розвитку системи вищої освіти на рівні регіону має підпорядковуватися реформаторським настановам нового Закону України «Про вищу освіту» (набув чинності 6 вересня 2014 р.). На часі реалізація таких напрямів реформ, як унормування сучасної організації вищої освіти, забезпечення автономії і академічної свободи, створення національної та регіональної системи забезпечення якості вищої освіти, ISSN 2616-6216. Publ. upr. reg. rozvit. 2020, 8: 596-617 
«Public Administration and Regional Development»

https://pard.mk.ua/index.php/journal

упровадження нових стандартів вищої освіти та освітніх програм.

Стратегічними напрямами сучасної модернізації вищої освіти слід вважати упорядкування мережі закладів вищої освіти 3 концентрацією потенціалу і підвищити конкурентоспроможності. Контингент студентів має бути приведений у відповідність до реальної ресурсної бази вищої освіти регіону. Доцільно обмежити граничну чисельність ліцензованих місць у закладах, а головне кількість самих закладів вищої освіти. Необхідно укрупнити існуючі вищі навчальні заклади шляхом їх об’єднання в потужні регіональні заклади вищої освіти.

Узагальнюючи напрями стратегічного планування розвитку регіональної освіти, слід виділити глобальні, інтегруючі його напрями на основі виокремлення кола пріоритетних проблем. Це упорядкування та осучаснення мережі закладів освіти всіх рівнів; стандартизація нормативів якості освіти; створення нової економіки освіти; концентрація інноваційно-технологічних ресурсів; запровадження державно-громадської моделі управління освітою, розвиток соціального партнерства у розв'язанні освітніх проблем. Щоби регіональна стратегія в освітній сфері забезпечувала доступ до якісної освіти, враховувала вимоги соціально-економічного розвитку регіону, вкрай важливо розробити, цілеспрямовану регіональну програму інноваційного розвитку освіти. Найважливішим у їі розробленні і впровадженні є досягнення реальної взаємодії чинників: політичного, соціального, економічного, культурного i, власне, освітнього. Таке поєднання дасть змогу вивести проблему якості освіти за межі суто галузевої проблематики, збалансувати пріоритети, створити систему безперервної освіти [7, с.19]. Ця система має розвиватися на основі нормативного і змістового узгодження всіх їі ланок, організаційного взаємодоповнення формальної, неформальної та інформальної освіти. Стратегічний пріоритет освітньої стратегії - формування регіональної спільноти, яка постійно навчається, засвоюючи одночасно демократичні цінності, розвиваючи громадянське суспільство, утверджуючи людиноцентризм в освіті.

Висновки. Таким чином, стратегічне планування розвитку 
Проблемно-цільові засади стратегічного планування розвитку системи освіти регіону регіональної освіти $є$ ефективним механізмом забезпечення іiі реформування у контексті потреб громадян та економіки. Його ефективність визначається розумінням пріоритетних проблем освітнього розвитку та їх взаємоузгодженності 3 соціальноекономічним розвитком регіону. Необхідна інтегрована стратегія здійснення інновацій як в усіх сферах освіти, так і в інших сферах життєдіяльності регіону. Це вимагає зростання управлінських функцій регіональної влади та місцевого самоврядування щодо планування та забезпечення освітніх реформ у регіоні.

\section{Стаття надійшла до редакції: 05.04.20}




\section{PROBLEM-GOAL PRINCIPLES OF STRATEGIC PLANNING OF THE REGIONAL EDUCATION SYSTEM DEVELOPMENT}

Viktor Sychenko, Doctor of Science in Public Administration, Professor, CIHE "Dnipro Academy of Continuing Education, Dnipro, Ukraine

Maiya Khytko, $\mathrm{PhD}$ in Public Administration, Docent of the Department of Public Administration and Law of , CIHE "Dnipro Academy of Continuing Education, Dnipro, Ukraine

The article examines the need and features of strategic planning of educational development at the regional level using existing problems as a basis for goal-setting management activities. Based on a systematic analysis and separation of common and special in the trends of educational development at the level of the country and the region, the basic problems of strategic planning and management are determined. At the national level, the basis of strategic planning for the development of education is the development of a new goal for the development of Ukrainian education based on the values of a democratic society, personal development, orientation to the European educational space. The generalized analysis of development of regional system of education on an example of the Dnepropetrovsk area with an exit on statement of the strategic purposes of its reforming is carried out. The problems of strategizing education management at the regional level and the need for related innovations in the regulatory and organizational sphere are emphasized. In order for the regional strategy in the field of education to provide access to quality education, take into account the requirements of socio-economic development of the region, it is extremely important to develop a purposeful regional program of innovative development of education. The most important in its development and implementation is to achieve real interaction of factors: political, social, economic, cultural 614 
Проблемно-иільові засади стратегічного планування розвитку системи освіти регіону and, in fact, educational. Based on the study, proposals are made to improve the strategic planning of the main components of the regional education system. The strategic priority of the educational strategy is the formation of a regional community that is constantly learning, while mastering democratic values, developing civil society, and affirming human-centeredness in education. An integrated strategy for innovation is needed in all spheres of education, as well as in other spheres of life in the region.

Key words: strategic planning, regional management, regional education system, optimization of public administration.

\section{Received:24.06.20}

\section{References}

1. Demohrafichna ta sotsialna statystyka. Osvita (Demographic and social statistics. Education) Електронний ресурс: http://www.dneprstat.gov. ua/statinfo/o/2019/o1.pdf. Дата звернення: 20.06.2020. [in Ukrainian].

2. Lyubchuk O.K. (2010). Teoretyko-metodolohichni zasady derzhavnoho upravlinnia neperervnoiu osvitoiu v Ukraini ta yii rehionakh / O.K. Lyubchuk, Kupryianov V. S.// Theoretical and methodological principles of public administration of continuing education in Ukraine and its regions. - Donetsk, 395 p. [in Ukrainian].

3. Melnyk Y. V. (2015). Teoretychni ta orhanizatsiini osoblyvosti modernizatsii upravlinnia sferoiu osvity / Y. V. Melnyk // Theoretical and organizational features of modernization of education management: regional aspect : author's ref. dis. ... cand. Sciences of the state. gov., Lviv, 20 p. [in Ukrainian].

4. Natsionalna dopovid pro stan i perspektyvy rozvytku osvity v Ukraini (National report on the state and prospects of education in Ukraine), NAPNU, Kyiv, (2016), 224 p. [in Ukrainian].

5. Odaynyk S.F. (2015). Upravlinnia yakistiu zahalnoi serednoi osvity v rehioni: teoretyko-metodolohichnyi aspekt / S.F. Odaynyk // Management of quality of general secondary education in the region: theoretical and methodological aspect, Aylant, Kherson, 263 p. [in Ukrainian].

6. Pastovensky O.V. (2014). Naukovi osnovy hromadsko-derzhavnoho 
«Public Administration and Regional Development»

https://pard.mk.ua/index.php/journal

upravlinnia zahalnoiu serednoiu osvitoiu v rehioni / O.V. Pastovensky // Scientific bases of public-state management of general secondary education in the region, Ruta, Zhytomyr, 383 p. [in Ukrainian].

7. 7. Revko A.M. (2019) Osvitnia dominanta u paradyhmalnomu vymiri sotsiohumanitarnoho prostoru rehionu / A.M. Revko, O. V. Brahynets // Educational dominant in the paradigmatic dimension of socio-humanitarian space of the region [vyd.], Chernihiv, 353 p. [in Ukrainian].

8. Sychenko V.V. (2016). Socialium rationem ac viam nosse status socialis policy in consilio / V.V. Sychenko // Publica administrationem et administratione consuetudines. \# II (XV). - p. 77-81. [in Ukrainian].

9. Sychenko V.V. (2018). Rei publicae consilium Ucraina in agro perdurantes educationem / V.V. Sychenko, S.O. Rybkina, O.M. Martynenko// Publico administrationem et administratione consuetudines. \# I (XVIII). - p. 74-79. [in Ukrainian].

10. Sychenko V.V. (2019). Proprietates opportuna consilio in educatione, sicut instrumentum administrationis publici / V.V. Sychenko, M.M. Khytko// Dissertatio medica contingunt, technologiae provectus, innovations (materiae, ex scientific practical colloquium International V). - Nemoros s.r.o.: Praga - p. 117-121 [in Ukrainian].

11. Tulchynska S.O. (2012). Upravlinnia u sferi osviti i nauki yak faktor zabezpechennia staloho rozvytku derzhavy ta rehioniv / Tulchynska S.O., Melnychenko A.A., Akimova O.A. //Management in the field of education and science as a factor in ensuring sustainable development of the state and regions), Edelveis, Kyiv, 328 p. [in Ukrainian].

12. Shevchuk A.V. (2013). Rehionalni osvitni systemy: teoriia, metodolohiia, praktyka innovatsiinoho rozvytku / A.V. Shevchuk // Regional educational systems: theory, methodology, practice of innovation development, Inst. Region. research. NAS of Ukraine, Lviv, 463 p. [in Ukrainian].

13. Yurchuk L.M.(2012). Teoretyko-metodolohichnizasady ta mekhanizmy derzhavno-hromadskoho upravlinnia rehionalnoiu systemoiu osvity / L.M. Yurchuk // Theoretical and methodological principles and mechanisms of state and public administration of the regional education system), Balyuk I.B., Vinnytsia, 398 p. [in Ukrainian]. 
Відомості про авторів / Information about the Authors

Сиченко Віктор Володимирович: Комунальний заклад вищої освіти «Дніпровська академія неперервної освіти», вул. Володимира Антоновича 70, м. Дніпро, 49006, Україна

Viktor Sychenko: Communal Institution of Higher Education "Dnipro Academy of Continuing Education", st. Antonovich, 70, Dnipro, 49006, Ukraine

\section{ORCID.ORG/0000-0001-9655-2317}

\section{E-mail: sychenko@dano.dp.ua}

Хитько Майя Миколаївна: Комунальний заклад вищої освіти «Дніпровська академія неперервної освіти», вул. Володимира Антоновича 70, м. Дніпро, 49006, Україна

Maiya Khytko: Communal Institution of Higher Education "Dnipro Academy of Continuing Education”, st. Antonovich, 70, Dnipro, 49006, Ukraine

ORCID. ORG/ 0000-0002-9216-8876

E-mail: maiya.hitko@gmail.com 